Synthesis of Natural Products and Drugs

\section{Key Words}

oxidation

D. J. MALONEY, J.-Z. DENG, S. R. STARCK, Z. GAO, S. M. HECHT* (UNIVERSITY OF VIRGINIA, CHARLOTTESVILLE, USA)

(+)-Myristinin A, a Naturally Occurring DNA Polymerase $\beta$ Inhibitor and Potent DNA Damaging Agent J. Am. Chem. Soc. 2005, 127, 4140-4141.

\title{
Total Synthesis of (+)-Myristinin A, a Potent DNA-Damaging Agent
}

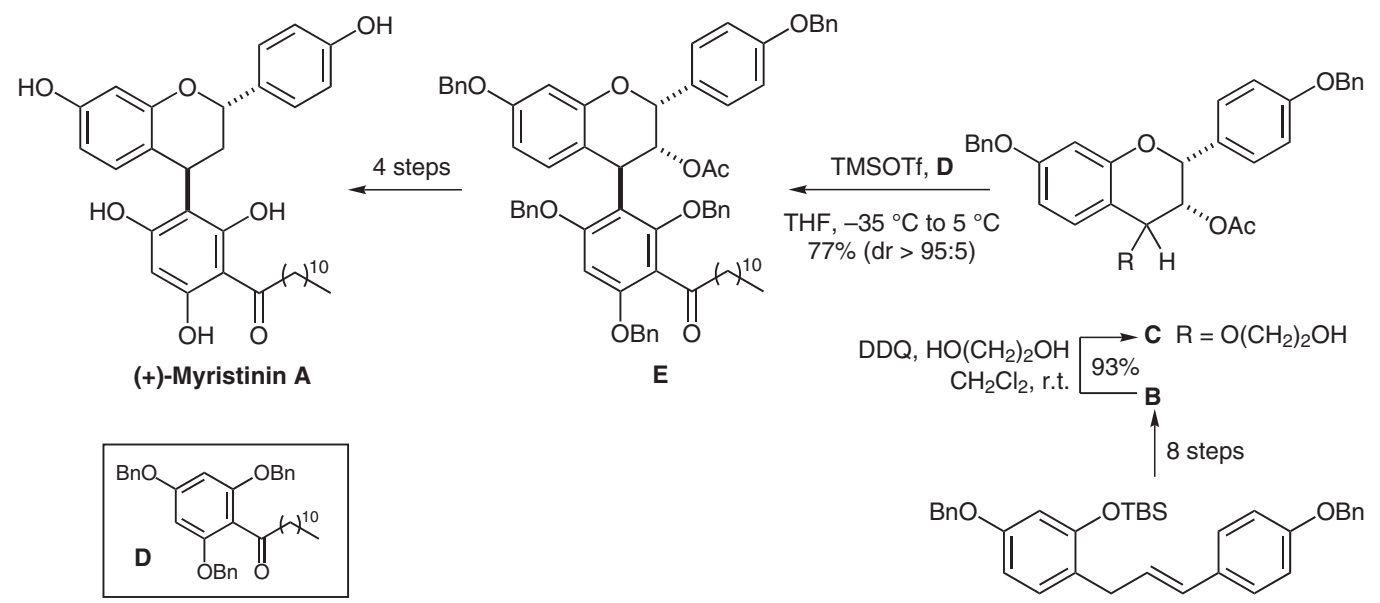

A

Significance: Myristinin A is a flavanoid recently isolated from Myristica cinnamomea and Knema elegans. It displays DNA-damaging and polymerase $\beta$ inhibitory activity. Hecht and co-workers provide details of the absolute stereochemistry of the natural product as well as biological studies related to its DNA-cleaving abilities.
Comment: The key step in this synthesis is the benzylic oxidation of $\mathbf{B}$ to generate $\mathbf{C}$ in excellent yield. Installation of this 4-O-alkylated moiety allows the Lewis acid-induced incorporation of $\mathbf{D}$ with excellent stereocontrol (>95:5) affording E. 